\title{
An Experimental Study of the Effects of Camelina Sativa Biodiesel-Diesel Fuel on Exhaust Emissions in a Turbocharged Diesel Engine
}

\author{
Hasan Aydogan, A. Engin Ozcelik, and Mustafa Acaroglu
}

\begin{abstract}
The aim of this study in diesel engines using fuel that can be produced with indigenous resources, renewable energy Camelina sativa biodiesel fuel, which is to investigate the use of the facilities. In recent years, both in the countries of the European Union, as well as the number of engine vehicles in Turkey diesel is increasing rapidly. Fossil fuels used in these engines work on the use of alternative energy sources are made. One of these alternative fuels, biodiesel. In this study, the use of fossil fuel diesel engines, which can be produced with indigenous resources, renewable energy Camelina biodiesel fuel, which was aimed to investigate the use of the facilities. In experiments diesel fuel and percent 20, 50 is used Camelina biodiesel blends. In experiments with common rail fuel system, turbocharged engine is used. Engine emissions of different fuel usage is examined.
\end{abstract}

Index Terms-Biofuels, Camelina sativa biodiesel, engine emissions.

\section{INTRODUCTION}

Industrial economy of a country is very much dependent on non-renewable fossil resources like coal, petroleum and natural gas with applications in electric generators, power plants, heavy trucks, locomotives and mining equipment. This ever increasing drift of energy consumption is not sustainable due to unequal geographical distribution of fossil fuels as well as environmental, geopolitical and economic concern [1]-[3].

Besides, use of fossil fuel triggers a huge amount of greenhouse gas and noise hence polluting the environment. This twin crisis of fossil fuel depletion and environmental degradation have motivated researchers to explore and evaluate the performance of alternative fuels such as biodiesel, bio hydrogen, bioethanol etc. in internal combustion engine [4]-[6].

Biodiesel can be used in modern unmodified diesel engines [7]. Therefore, it is a favor- able alternative to conventional energy sources, which will help to decrease the release of greenhouse gas [8], [9].

Camelina, which occurs naturally in the Mediterranean and Central Asia is annual herbaceous plant. Is a plant known since year 3000, Europe was produced until 1960. Then, this plant is replace of rapeseed. Camelina plant in Turkey, Japan and the United States Camelina oil is used as aircraft fuel was on the topic. Oil content of camelina seeds ranges from 25 to

Manuscript received December 13, 2015; revised March 2, 2016.

The authors are with the Department of Mechanical Engineering, Technology Faculty, Selcuk University Campus, Selcuklu, Konya, 42250 Turkey (tel.: +90-332-2233339, e-mail: haydogan@selcuk.edu.tr, eozcelik@selcuk.edu.tr, acaroglu@selcuk.edu.tr).
$45 \%$. Camelina oil is $90 \%$ of unsaturated fatty acids, of which about $57 \%$ of polyunsaturated fatty acids (omega- 3 and omega-6) is composed. Due to Camelina oil has got 2-6\% erucic acid, it restricts the use edible. Soil requirements in terms of salinity and drought as being highly selective in terms of resistance from many oil plants are more tolerant [10].

Today, diesel engines are widely used in transportation, industry and agricultural areas because of their high fuel efficiency and ease of operation. The demand for diesel engines has been continuing to increase worldwide as a result of expanding industrialization. This is because diesel engines have certain advantages compared to spark ignition engines such as low fuel consumption, high engine torque and longevity. Despite these advantages, today diesel engines are among the leading factors that cause air pollution. In our day, studies are conducted on changing certain engine operating parameters such as valve timing, injection timing and rate in order to decrease harmful emissions. In addition, researchers have been conducting studies on various renewable fuels such as biodiesel and alcohols because of the decrease in the reserves of fossil energy sources and their negative effects on the environment.

Biodiesel has received significant attention in all countries since it is nontoxic, biodegradable and renewable diesel fuel. Biodiesel is generally produced from cooking vegetable oils. Using high-quality virgin oils makes biodiesel more expensive than diesel fuel and it causes to increase in vegetable oil prices. Therefore, low cost feedstocks are needed and should be used in biodiesel production. In Turkey, B2 (2\% biodiesel, 98\% diesel fuel) usage is excise tax free for biodiesel produced from waste cooking vegetable oils. However, there are different biodiesel feedstocks to be used in the production. For example, rendered animal fats and leather industry wastes are appealing feedstocks to produce biodiesel so that there is no conflict with food production [7]-[9].

Cameline sativa yields anywhere from 336 to $2240 \mathrm{~kg}$ of seeds per hectare at maturity, with the lipid content of individual seeds ranging between 35 and 45 wt. $\%$ with 27-32 wt.\% protein content. C. sativa oil contains approximately $90 \%$ unsaturated fatty acids. This unusual fatty acid pattern is due to the abundance of C18:1 (12.8- 14.7 wt.\%), C18:2 (16.3-17.2 wt.\%), C18:3 (36.2-39.4 wt.\%) and C20:1 $(14.0-15.5 \mathrm{wt} . \%)$ fatty acids. This level of unsaturation would most likely make the unhydrogenated oil unsuitable for food-related applications because the oil would likely be prone to autoxidation. In addition, the physiological effects of eicosenoic acid are not well understood [9], [10]. 
Although CSB along with its properties have already been re- ported the present study provides a more comprehen- sive fuel property assessment not found in the literature to date. The aim of the present work was to conduct a complete character- isation of $\mathrm{C}$. sativa biodiesel (CSB) according to the ASTM D6751 and EN 14214 standards. The standard requirements are based on the desire to ensure that biodiesel is of adequate purity, quality and stability to ensure engine and fuel component durability and reliability. For the first time, a set of thirty parameters was analysed. The values for six of these parameters, all directly related to the fatty acid profile, did not meet the standard requirements. These so-called structure indices originally served to exclude the use of certain vegetable oils or animal fats as feedstocks.

When previous studies were examined, it was seen that there were no studies on the use of camelina biodiesel in a diesel engine with a common rail injection system. In the present study, the effects of two different camelina biodiesel fuel ratios obtained through transesterification on engine emissions of these fuels compared to diesel fuel were examined.

\section{MATERIAL AND METHOD}

A 1.9 multijet diesel engine was used in engine tests (Table I). The tests were carried out on the hydraulic engine dynamometer with the specifications presented in Table II. All the tests were conducted at full-throttle opening. Before starting the tests, the engine was operated until it reached a stable condition. Afterward, the experiments were started.

In the tests, $\mathrm{NO}_{x}, \mathrm{HC}, \mathrm{CO}_{2}$ emission values of diesel fuel, B20 and B50 fuels were carried out by using Bosch BEA 350 model emission measurement test equipment (Table III). General view of the test platform is shown in Fig. 1.

TABLE I: TECHNICAL SPECIFICATIONS OF THE TEST ENGINE

\begin{tabular}{ll}
\hline \multicolumn{2}{c}{ Engine } \\
\hline Cylinder number and layout & \multicolumn{1}{c}{ 1.9 Multijet diesel engine } \\
Cylinder volume $(\mathrm{cc})$ & 1910 \\
Compression ratio & $18.5: 1$ \\
Maximum power $\mathrm{HP}-\mathrm{rpm}$ & $105-4000$ \\
Maximum torque Nm $(\mathrm{kgm})-\mathrm{rpm}$ & $200-1750$ \\
Fuel & Diesel \\
Fuel feed & Electronically controlled Common Rail type Multijet \\
Ignition & direct injection, turbo and intercooler \\
Diameter x Stroke $(\mathrm{mm})$ & Compression \\
\hline
\end{tabular}

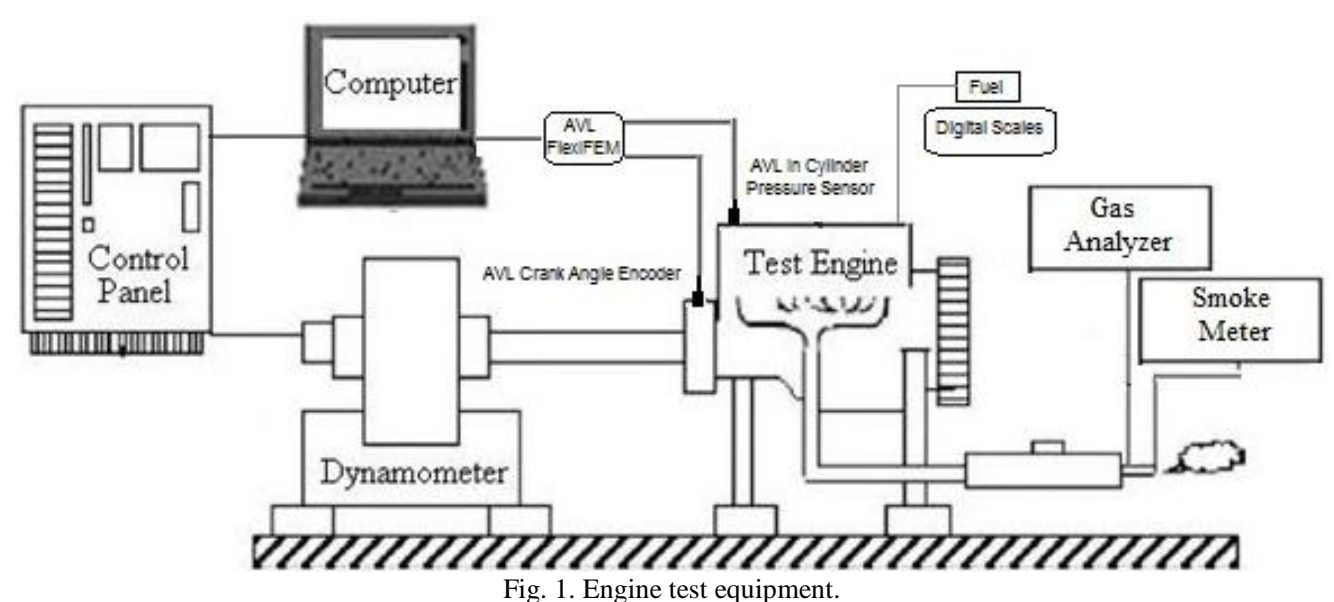

Fig. 1. Engine test equipment.

TABLE II: TECHNICAL SPECIFICATIONS OF THE HYDRAULIC DYNAMOMETER USED IN THE STUDY

\begin{tabular}{ll}
\hline Brake model & BT-190 FR \\
\hline Maximum brake power & $100 \mathrm{~kW}$ \\
Maximum speed & $6000 \mathrm{~d} / \mathrm{d}$ \\
Maximum torque & $750 \mathrm{Nm}$ \\
Brake water operating pressure & $0-2 \mathrm{~kg} / \mathrm{cm}^{2}$ \\
Water needed for maximum power & $2,3 \mathrm{~m}^{3} / \mathrm{hr}$ \\
Brake water exit maximum temperature & $80{ }^{\circ} \mathrm{C}$ \\
Torque measurement & Electronic load-cell \\
Rotation direction & Right and left rotation \\
\hline
\end{tabular}

TABLE III: TECHNICAL SPECIFICATIONS OF THE EXHAUST EMISSION MEASURING DEVICE

\begin{tabular}{ccc}
\multicolumn{3}{c}{ MEASURING DEVICE } \\
\hline Parameters & $\begin{array}{c}\text { Measuring } \\
\text { range }\end{array}$ & Precision \\
\hline $\mathrm{HC}$ & $0-20.000 \mathrm{ppm}$ & $1 \mathrm{ppm}$ \\
$\mathrm{CO}_{2}$ & $0-20 \%$ & $0.1 \%$ \\
$\mathrm{CO}$ & $0-15 \%$ & $0.001 \%$ \\
$\mathrm{O}_{2}$ & $0-21.7 \%$ & $0.01 \%$ \\
$\mathrm{NO} x$ & $0-5000 \mathrm{ppm}$ & $1 \mathrm{ppm}$ \\
\hline
\end{tabular}

Diesel fuel and camelina oil were used as material in this study. The properties of raw camelina oil and diesel fuel are presented in Table IV. Camelina seeds obtained after the harvest were subjected to hot press at $85^{\circ} \mathrm{C}$ to produce raw oil. The raw oil was filtered and biodiesel was obtained through transesterification by using methanol as alcohol and $\mathrm{NaOH}$ as catalyzer. EN 14214 standard test methods were taken as reference in measuring the obtained values.

The density measurement experiment was conducted by using the KEM Density/Specific Gravity Meter DA-505. The device operates through resonant frequency measuring method. The measuring range is $0-3 \mathrm{~g} / \mathrm{cm}^{3}$, operating temperature is $4-90{ }^{\circ} \mathrm{C}$, margin of error in density measurements is $\pm 0.00005 \mathrm{gr} / \mathrm{cm}^{3}$, manual measuring time is 1-4 minutes and 2-10 minutes in programming code.

The device used for kinematic viscosity measurement was Koehler K23377 model with operating temperature range 
between 25 and $150{ }^{\circ} \mathrm{C}$ and a temperature sensitivity of \pm 0.01 . Viscosity measurement can be performed according to ASTM D 445, DIN 51550 and ISO 3104 standards.

TABLE IV: COMPARISON OF THE PROPERTIES OF RAW CAMELINA OIL AND DIESEL FUEL

\begin{tabular}{lcc}
\hline Properties & $\begin{array}{c}\text { Raw } \\
\text { camelina oil }\end{array}$ & Diesel \\
\hline Density $15^{\circ} \mathrm{C}\left(\mathrm{kg} / \mathrm{m}^{3}\right)$ & 918 & 838 \\
Kinematic viscosity $40{ }^{\circ} \mathrm{C}$ & 24 & 2.92 \\
$\mathrm{~mm}^{2} / \mathrm{s}$ & $>220$ & 102 \\
Flash point ${ }^{\circ} \mathrm{C}$ & 38 & 42.3 \\
Lower heating value $(\mathrm{MJ} / \mathrm{kg})$ & 0.0025 & 0.01 \\
Ash $(\%$ mass $)$ & 13.85 & 9 \\
sulfur $(\mathrm{mg} / \mathrm{kg})$ & 710 & 43.8 \\
Water content $(\mathrm{mg} / \mathrm{kg})$ & 1.39 & - \\
Acid value $(\mathrm{mg} \mathrm{KOH} / \mathrm{g})$ & 151.5 & - \\
Iodine number $\left(\mathrm{g} . \mathrm{I}_{2} / 100 \mathrm{~g}\right)$ & & \\
\hline
\end{tabular}

All the tests were conducted at full-throttle opening. Before starting the tests, the engine was operated until it reached a stable condition. Afterwards, the experiments were started. All the experiments were repeated for three times and means of the obtained values were calculated.

\section{RESULTS AND CONCLUSION}

$\mathrm{CO}_{2}$ is a natural gas that forms as the result of burning. However, increasing amounts of $\mathrm{CO}_{2}$ in the atmosphere causes the formation of greenhouse gasses and global warming. $\mathrm{CO}_{2}$, which is among exhaust products, is a highly important parameter since it represents full combustion [11].

The $\mathrm{CO}_{2}$ values of fuels with respect to engine speed are given in Fig. 2. The results show that the $\mathrm{CO}_{2}$ emission values of diesel fuel are on average $20 \%$ less compared to those of B7 and B100 fuels. Biodiesel contains oxygen. For this reason, extra oxygen is added to the air taken into the cylinder. Combustion improves with the increase of the amount of $\mathrm{O}_{2}$ taken into the cylinder and the amount of $\mathrm{CO}_{2}$ that occurs as the result of the process also increases.

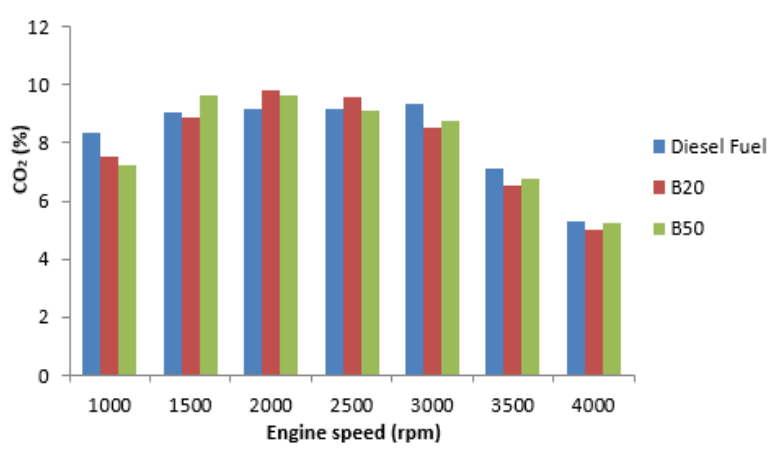

Fig. 2. $\mathrm{CO}_{2}$ emissions in diesel fuel and biodiesel blends.

$\mathrm{HC}$ represents unburned fuel. HC values of the fuels with respect to engine speed are given in Fig. 3. HC value of B7 fuel was found to be $37.5 \%$ lower and $\mathrm{HC}$ value of B100 fuel was found to be $68.8 \%$ lower compared to that of diesel fuel. These values are compatible with the amount of $\mathrm{CO}_{2}$ in the exhaust gas. As can be seen from the ratios, $\mathrm{HC}$ emission decreased as blend ratio increased. The primary reason for the decrease in $\mathrm{HC}$ emissions is that the oxygen content of biodiesel maintains adequate oxidation, that is, burning in rich air-fuel mixture zones. High $\mathrm{HC}$ emissions at low engine speeds is because of the fact that specific fuel consumption is also high at these engine speeds. Engine type also has an effect on these values [12]. High engine compression ratio is also among the factors that cause high HC emissions.
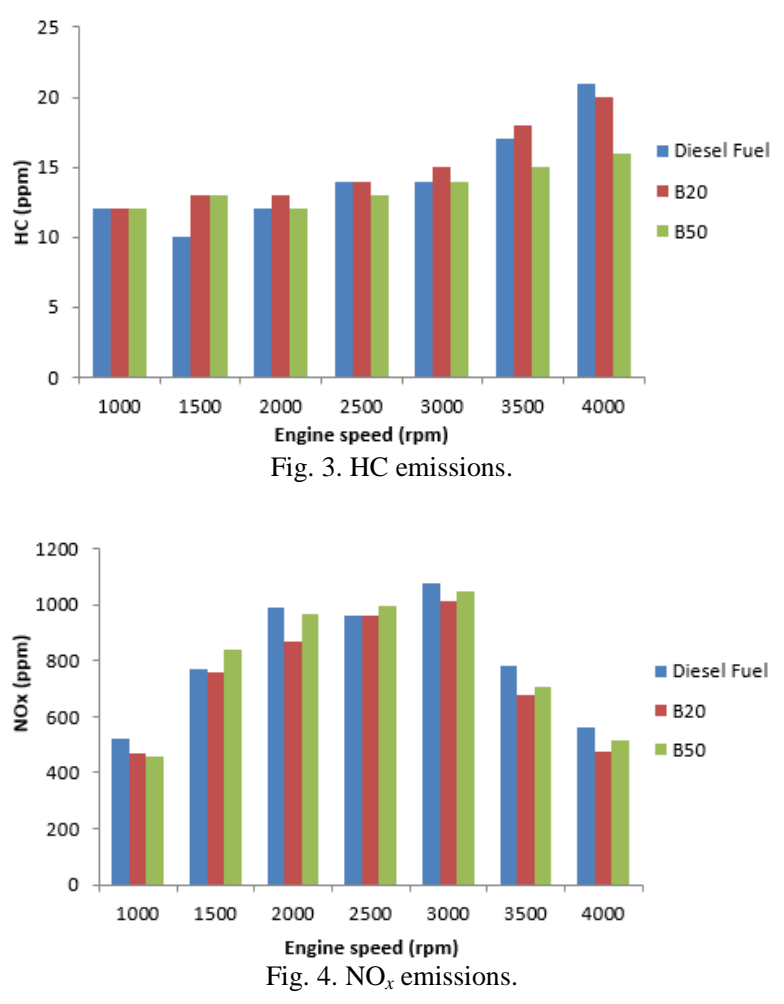

In engines, the combination of the nitrogen in the air with oxygen at high temperatures reached as the result of combustion decreases $\mathrm{NO}_{x}$ emissions [13]. For this reason, real $\mathrm{NO}_{x}$ values were found by using the humidity correction factor defined by SAE 2001 [14]. The $\mathrm{NO}_{x}$ values of the fuels with respect to engine speed are presented in Fig. 4. $\mathrm{NO}_{x}$ values were found to be $17.6 \%$ higher in B20 fuel and $58.8 \%$ higher in B100 fuel on average compared to diesel fuel. For $\mathrm{NO}_{x}$ formation, $\mathrm{N}, \mathrm{O}_{2}$ and high temperature are needed in the environment. During the combustion process, oxygen and nitrogen reacts with each other at high temperatures and this reaction causes $\mathrm{NO}_{x}$ emissions. Main part of $\mathrm{NO}_{x}$ emissions consists of $\mathrm{NO}$ emis- sions while $\mathrm{NO}_{2}$ emissions are the small part of $\mathrm{NO}_{x}$ emissions. The rest trace amount of $\mathrm{NO}_{x}$ emissions are composed of other oxygen-nitrogen combinations. The emissions of $\mathrm{NO}_{\mathrm{x}}$ emissions are mainly due to oxygen in air. However, some diesel fuels may have trace amount of nitrogen molecules in their structure but the nitrogen content in the fuel have little effect on $\mathrm{NO}_{x}$ emissions. The emissions of $\mathrm{NO}_{x}$ depend on cylinder temperature, pressure, air-fuel ratio and combustion duration. In addition, some fuel proper- ties such as viscosity and bulk modulus also affect the $\mathrm{NO}_{x}$ emissions. Humidity has an important effect on $\mathrm{NO}_{x}$ emissions. An increase in air humidity causes a reduction in $\mathrm{NO}_{x}$ emissions. Therefore, humidity values were measured to do humidity correction during all engine tests. The amount of $\mathrm{NO}_{x}$ increases as the amount of $\mathrm{O}_{2}$ increases in the environment. The increase in $\mathrm{NO}_{x}$ here can be explained by the $\mathrm{O}_{2}$ content of biodiesel. Furthermore, specific fuel consumption of biodiesel blends is higher compared to that of diesel fuel and the oxygen content increases the oxidation in 
fuel-rich zones, which increases the number of combustion zones. The increase in the number of zones with high environmental temperature also increased the formation of $\mathrm{NO}_{x}$ emissions [15].

\section{CONCLUSION AND SUGGESTIONS}

In the present study, engine emission were examined in a four-cylinder, water-cooled, four-stroke, turbo charged, intercooler, common rail fuel system diesel engine. Camelina biodiesel (B20 and B50) and diesel fuel blends were used as test fuel. The obtained results were compared with those of diesel fuel. The main results were obtained as follows:

- $\mathrm{CO}_{2}$ emission of diesel fuel was found to be approximately $20 \%$ lower compared to that of B20 and B50 fuels. The reason for this difference is that as the oxygen content of biodiesel increases, combustion improves and the amount of $\mathrm{CO}_{2}$ formed also increases.

- $\mathrm{HC}$ values of B20 fuel decreased $37.5 \%$ compared to diesel fuel and HC values of B50 fuel decreased 68.8\% compared to diesel fuel. As the blend ratio of biodiesel increases, the oxygen content of biodiesel maintains adequate oxidation, that is, burning in rich air-fuel mixture zones.

- $\mathrm{NO}_{x}$ values were found to be $17.6 \%$ higher with B20 fuel and $58.8 \%$ higher with B50 fuel compared to diesel fuel. The increase in the number of zones with high environmental temperature also increased the formation of $\mathrm{NO}_{x}$ emissions.

- C. sativa contains a high percentage of oil (>40 wt.\%) that can be easily extracted and refined. Moreover, this oil can be easily transesterified using homogeneous alkali catalysis. However, the obtained biodiesel does not meet all of the quality specifications in the EN 14214 and ASTM D6751 standards. C. sativa biodiesel presents serious drawbacks for biodiesel applications; the linolenic acid methyl ester content, polyunsaturated (P4 double bonds) methyl ester content, iodine value, cetane number and oxidation stability do not satisfy the limits of EN 14214.

When the results obtained in this study and similar studies are examined, different blends of biodiesel are highly important in terms of engine emissions when the concepts of environment and sustainability are taken into account.

\section{ACKNOWLEDGMENT}

This study was supported by The Scientific and Technological Research Council of Turkey (TUBITAK) (project no 114M838). The authors would like to thank the individuals who were involved in making this work possible.

\section{REFERENCES}

[1] A. Sanjid, H. H. Masjuki, M. A. Kalam, M. J. Abedin, and S. M. A. Rahman, "Experimental investigation of mustard biodiesel blend properties, performance, exhaust emission and noise in an unmodified diesel engine," APCBEE Procedia, vol. 10, pp. 149-153, 2014.
[2] P. D. Patil, V. G. Gude, L. M. Camacho, and S. Deng, "Microwave-assisted catalytic transesterification of Camelina sativa oil," Energy Fuels, vol. 24, pp. 1298-1304, 2010.

[3] A. Sanjid, H. H. Masjuki, M. A. Kalam, S. M. A. Rahman, M. J. Abedin, and S. M. Palash, "Impact of palm, mustard, waste cooking oil and Calophyllum inophyllum biofuels on performance and emission of CI engine," Renewable and Sustainable Energy Reviews, vol. 27, pp. 664-682, 2013.

[4] M. Patrick and K. Amit, "Development of emission parameters and net energy ratio for renewable diesel from canola and Camelina," Energy, vol. 58, pp. 426-437, 2013.

[5] M. J. Abedin, H. H. Masjuki, M. A. Kalam, A. Sanjid, S. M. A Rahman, and B. M. Masum, "Energy balance of internal combustion engines using alternative fuels," Renewable and Sustainable Energy Reviews, vol. 26, pp. 20-33, 2013.

[6] Y. Sun, H. K. Reddy, T. Muppaneni et al., "A comparative study of direct transesterification of Camelina oil under supercritical methanol, ethanol and 1-butanol conditions," Fuel, vol. 135, pp. 530-536, 2014.

[7] R. Lin, Y. Zhu, and L. L. Tavlarides, "Effect of thermal decomposition on biodiesel viscosity and cold flow property," Fuel, vol. 117, pp. 981-988, 2014.

[8] G. Anitescu and T. J. Bruno, "Biodiesel fuels from supercritical fluid processing: quality evaluation with the advanced distillation curve method and cetane numbers," Energy Fuels, vol. 26, pp. 5256-5264 2012.

[9] V. G. Gude and G. E. Grant, "Biodiesel from waste cooking oils via direct sonication," Appl. Energy, vol. 109, pp. 135-144, 2013.

[10] G. Yılmaz, A. Kınay, and S. Ayışı̆̆ı, "Ketencik (Camelina Sativa) bitkisinin tanitimi ve yetiştiriciliği," Enerji Tarımı ve Biyoyakıtlar 4 Ulusal Çalıştayı, 28-29 Mayıs 2014, Samsun, Turkey.

[11] L. M. Rodriguez-Anton, J. Casanova-Kindelan, and G. Tardajos, "High pressure physical properties of fluids used in diesel injection systems," SAE Paper, No. 2000-01-2046, 2000.

[12] K. Schmidt and J. van Gerpen, "The effect of biodiesel fuel composition on diesel combustion and emissions," SAE Paper, No. 961086, 1996.

[13] A. A. Abdel-Rahman, "On the emissions from internal-combusiton engines: A review," Int. J. Energy Res, vol. 22, pp. 483-513, 1998.

[14] Society of Automotive Engineers, Warrendale, MI: SAE Handbook Inc., 2001, vol. 1, pp. 1304-1306.

[15] E. Alptekin, M. Canakci, A. N. Ozsezen, A. Turkcan, and H. Sanli, "Using waste animal fat based biodiesels-bioethanol-diesel fuel blends in a DI diesel engine," Fuel, vol. 157, pp. 245-254, 2015.

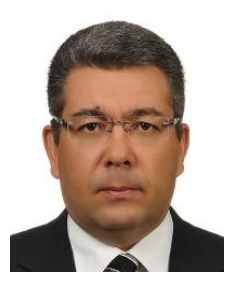

Hasan Aydogan was born in Eskisehir, Turkey. He is an Assoc. Prof. at Selcuk University. His research are mainly focus in energy, biofuel and internal combustion engine.

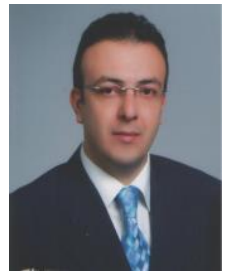

Engin Özçelik was born in Beyşehir, Konya. He graduated from Sakarya University, Faculty of Technical Education in 2001. Then he finished his $\mathrm{PhD}$ program in November 2011. He is a research assistant at Selcuk University now and studying with energy issue.

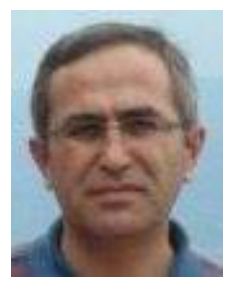

Mustafa Acaroğlu was born in Gokyurt, Turkey. He graduated from Konya Selcuk University, Faculty of Agricultural. He is working as a professor at the Selcuk University now. His research areas are energy and fuel issue. 


\section{Energy Management}


